\title{
The Relationship Between Educational Level of Fertile Age Women and Contraception Knowledge to Prevent the Unwanted Pregnancy in the COVID-19 Pandemic Era
}

\author{
Annita Viesta Nirmala Dewi ${ }^{1 *}$, Nudiya Salwa Syifa Kamila ${ }^{1}$, Siti Nurhidayati ${ }^{1}$ \\ Jurusan Kebidanan, Fakultas Kedokteran, Universitas Sebelas Maret, Jl. Ir. Sutami 36 A, Kentingan Surakarta \\ 57126 telp. (0271) 662622 \\ * Corresponding author \\ E-mail: contact.anitaviee@gmail.com
}

\begin{abstract}
Indonesia has the potential for a baby boom after the COVID-19 pandemic. The cause of this issue is the decline of contraception used by fertile age couples. The decline of contraception used lead to unwanted pregnancies. This study were conducted to find out the relationship about educational level in fertile age women regarding contraception. This cross-sectional study was done in 27 provinces in Indonesia and it was found about 279 fertile age women with different educational backgrounds. The respondents who met the inclusion criteria were married women by 104 people from 19 different provinces. The educational level groupings are intermediate (Middle School and High School), vocational (D1/D2/D3), and higher education (Bachelor/Master). The respondents were asked to answer questions about contraceptives through questionnaires distributed on social media. Next, the data were process by using univariate dan bivariate as well as the chi square test with 24 version of SPSS. The result showed that $53.8 \%$ of respondents who have good knowledge about contraception, respondents who have poor knowledge about contraceptives are $46.2 \%$. There is a relationship between educational level of fertile age women and knowledge about contraception ( $p$-value: 0,001 ), and the unmet need is one of the factors which causes unwanted pregnancies, therefore, the efforts are needed to eliminate unmet need to reduce the incidence of unwanted pregnancies during the COVID-19 pandemic.
\end{abstract}

Keywords: contraception, fertile age, education, unmet need, women

\section{INTRODUCTION}

The lower middle class people with low educational background are estimated to be the biggest problems to the baby boom that will be experienced by Indonesia since they have a greater risk of having an unwanted pregnancy in the pandemic era compared to the well-educated people. The reasons for the increase in the pregnancy rate are lack of public knowledge and difficult access to health care facilities to do a family planning programs. These cases are supported with a research in Papua New Guinea which discovered that there are $53.6 \%$ of women have knowledge to the danger signs of pregnancy from the clinic workers while the remaining $46.4 \%$ do not have knowledge because they do not get 
antenatal education related to the danger signs of pregnancy [1].

World Population Prospects recorded that the Total Fertility Rate in the world in 2018 was 2.467 children per woman [2]. Meanwhile in 2019 the Total Fertility Rate was 2.458 children per woman, and in 2020 showed a decrease of 0.41 to 2,448 children per woman [2]. Therefore, for 3 consecutive years the calculation of the Total Fertility Rate continues to decline although not significantly. The Total Fertility Rate in Indonesia in 2018 was 2.32 children per woman [2]. Whilst, the data in 2019 showed the number of 2.3 children per woman and in 2020 was 2.28 children per woman [3]. Thus, the TFR in Indonesia comparable to the decline in TFR in the world. Even if the TFR has decreased every year, the results of the population census in 2020 found Indonesia's population of 270.20 million people [2]. The number of population increase of 32.56 million people when compared to the census results in 2010 [4].

The 2020 Population Census pointed that productive age percentage (15-64 years old) was $70.72 \%$ [5]. Family Planning Programs by Badan Kependudukan dan Keluarga Berencana (BKKBN) has a big responsibility to reduce the birth rate or Total Fertility Rate (TFR) [6]. BKKBN targeted TFR to be 2.26 children per woman in 2020 according to government instruction [6]. However, United Nation (2020) recorded Indonesia TFR was 2.28 children per woman which indicated that BKKBN have not met the target [2].

Vollset et al., (2020) discovered the reason for the decline in birth rates in some countries is because women tend to delay marriage and childbirth because they choose to be more educated and working [7]. Kusyanto (2018) stated that the decline of fertility rate is also caused by the increase in the use of contraception due to interventions for family planning, modernization, and socio-economic development [8]. Meanwhile, the cause of the decline in the birth rate in Indonesia is the reduced birth rate due to community participation in family planning programs [6].

The World Bank stated that the birth rate will have a negative impact in various aspects [9]. The negative impact that will occur is the increase of maternal and child mortality rates due to no gap between pregnancies, uneven fulfillment of children's education due to difficulties in providing access to education, population growth gaps and economic growth due to high birth rates not being matched by an even population distribution, and natural imbalances due to high community needs to natural wealth without preserving its sustainability [9].

The government suppresses the high birth rate in Indonesia by promoting family planning programs, however, the government experiencing obstacles due to the COVID-19 pandemic in 2020. The government then took a big decision to carry out social restrictions to control the increasingly widespread transmission. The social restrictions eventually impacted in a lack of public contact with health workers who also began to focus on dealing with the pandemic. Therefore, the contraceptive users have decreased because access to contraceptive services is hampered. The data showed that the contraceptive users in February 2020 were 941.181, however in March 2020 recorded that there were 591.667 participants [6]. Hence, fertile age couples (PUS) with 4T (Too Young, Too Early, Too Often, Too Old) are expected to use the contraception in order to prevent an unwanted pregnancy.

The other government policies in health service especially in the Family Planning Services such as encourage fertile age couples to delay pregnancy, health workers who provide services are required to use PPE (Personal Protective Equipment) and clients are required to wear masks and make prior arrangements, health service officers in collaboration with Family Planning Field Officers to ensure the availability of pills and condoms and distribute to clients who need it, make it 
easier for the public to access information on family planning services.

Health workers who are able to contributed in suppressing the birth rate, one of which is a midwife, in accordance with the Law on Midwifery No. 4 of 2019 Article 46 states that midwives are tasked with providing services, one of them is about reproductive health and family planning programs together or independently. Article 47 of the same law states that midwives can act as providers and managers of midwifery services, extension workers, counselors as well as the activator and women empowerment. In addition, midwives are also authorized to provide education, information, communication, counseling and provide contraceptive services in accordance with applicable laws and regulations (Law No. 4, 2019).

Yulianti A (2020) stated that even if health services have met service standards, there are still some people who are reluctant to visit health care facilities for reproductive health checks or consultations regarding pregnancy for fear of being infected, the advices for postponing pregnancy, and the unpreparedness of services in terms of facilities and infrastructure. Sugi Purwanti, (2020) supported the statement with adding that the more incorrect information about COVID-19 has been spread on social media networks, making people even more afraid of getting infected when they are going to carry out family planning services [10].

\section{METHODS}

The data were from questionnaires distributed through social media such as Instagram, Twitter, and Whatsapp. The respondents' criteria were fertile age married women and live in Indonesia with various educational background. The respondents were asked to answer 18 questions which have previously been tested for validity and reliability tests so that they can represent their knowledge of contraceptives. The questions given include the definition, types, benefits, side effects, how to install, how it works, and the disadvantages of using contraceptives.

In accordance to the distributed questionnaires, were obtained 279 fertile age women come from 27 provinces with different educational backgrounds. The respondents who met the inclusion criteria namely married are 104 people from 19 different provinces. The education level groupings are, intermediate (Middle School and High School), vocational (D1/D2/D3), and higher education (Bachelor/Master/Doctoral).

First, the data were being clean to categorize the eligible and non-eligible data then perform coding and data processing using IBM SPSS version 24. The data that has been obtained were analyzed by using univariate and bivariate to determine whether or not there is a correlation between education and fertile age women knowledge regarding contraceptives.

\section{RESULT}

\begin{tabular}{lcc} 
A. Respondent Characteristics & \\
\hline No & Province & Sum \\
\hline $\mathbf{1 .}$ & Jawa Tengah & $\mathbf{3 2}$ \\
$\mathbf{2 .}$ & Jawa Timur & $\mathbf{2 1}$ \\
$\mathbf{3 .}$ & Jawa Barat & $\mathbf{1 0}$ \\
$\mathbf{4 .}$ & D.I. Yogyakarta & $\mathbf{3}$ \\
$\mathbf{5 .}$ & Jakarta & $\mathbf{4}$ \\
$\mathbf{6 .}$ & Banten & $\mathbf{4}$ \\
$\mathbf{7 .}$ & Lampung & $\mathbf{6}$ \\
$\mathbf{8 .}$ & Papua & $\mathbf{1}$ \\
$\mathbf{9 .}$ & Nusa Tenggara Barat & $\mathbf{1}$ \\
$\mathbf{1 0 .}$ & Gorontalo & $\mathbf{2}$ \\
$\mathbf{1 1 .}$ & Sumatera Selatan & $\mathbf{4}$ \\
$\mathbf{1 2 .}$ & Sumatera Utara & $\mathbf{1}$ \\
$\mathbf{1 3 .}$ & Sulawesi Selatan & $\mathbf{5}$ \\
$\mathbf{1 4}$. & Sulawesi Barat & $\mathbf{1}$ \\
$\mathbf{1 5 .}$ & Kalimantan Barat & $\mathbf{3}$ \\
$\mathbf{1 6 .}$ & Kalimantan Selatan & $\mathbf{2}$ \\
$\mathbf{1 7 .}$ & Bali & $\mathbf{2}$ \\
$\mathbf{1 8}$ & Sulawesi Tenggara & $\mathbf{1}$ \\
$\mathbf{1 9}$. & Sulawesi Tengah & $\mathbf{1}$ \\
& Total & $\mathbf{1 0 4}$ \\
\hline & &
\end{tabular}




\section{B. Univariat Analysis}

104 respondents were analyzed, consisting of 17 people from Middle School and High School education levels, 33 people from D1/D2/D3 educational backgrounds, and 54 people having Bachelor/Master educational backgrounds.

Table 1. Distribution of Fertile Age Women Knowledge Frequency Based on Middle School/High School Education Level

\begin{tabular}{cccc}
\hline No & Knowledge & Sum & Percentage \\
\hline 1. & Good & 4 & $23,5 \%$ \\
2. & Not Good & 13 & $76,5 \%$ \\
& Total & 17 & $100 \%$
\end{tabular}

Based on the first table, namely fertile age women with an educational background at Middle School and High School levels, it was found that $23.5 \%$ of respondents with good knowledge and the remaining $76.5 \%$ had poor knowledge.

Table 2. Distribution of Fertile Age Women Knowledge Frequency Based on D1/D2/D3 Education Level

\begin{tabular}{cccc}
\hline No & Knowledge & Sum & Percentage \\
\hline 1. & Good & 25 & $75,8 \%$ \\
2. & Not Good & 8 & $24,2 \%$ \\
& Total & 33 & $100 \%$
\end{tabular}

According to the second table, namely fertile age women with an educational background of D1/D2/D3, it was found that $24.2 \%$ of respondents had good knowledge and the remaining $75.8 \%$ had poor knowledge.

Table 3. Distribution of Fertile Age Women Knowledge Frequency Based on

Bachelor/Master Education Level

\begin{tabular}{cccc}
\hline No & Knowledge & Sum & Percentage \\
\hline 1. & Good & 27 & $50 \%$ \\
2. & Not Good & 27 & $50 \%$ \\
& Total & 54 & $100 \%$ \\
\hline
\end{tabular}

In accordance to the third table, namely fertile age women with an educational background at the
Bachelor/Master level, it was found that $50 \%$ of respondents had good knowledge and the remaining $50 \%$ had poor knowledge.

Table 4. Frequency Distribution of Respondents' Overall Knowledge

\begin{tabular}{cccc}
\hline No & Knowledge & Sum & Percentage \\
\hline 1. & Good & 56 & $53,8 \%$ \\
2. & Not Good & 48 & $46,2 \%$ \\
& Total & 104 & $100 \%$ \\
\hline
\end{tabular}

Based on the overall results of respondents with various educational backgrounds (table 4), 53.8\% of respondents had good knowledge and the remaining $46.2 \%$ had poor knowledge.

\section{Bivariate Analysis}

Table 5. The result of Bivariate Analysis between the WUS Knowledge of Contraceptives in Indonesia based on Education Level

\begin{tabular}{cccccccc}
\hline \multicolumn{6}{c}{ Educational Level } & \\
Know & \multicolumn{1}{c}{ SMP/ } & D1/D2/ & \multicolumn{2}{c}{ S1/S2 } & P-Value \\
-ledge & SMA & D3 & \multicolumn{2}{c}{-V } \\
& N & $\%$ & N & $\%$ & N & $\%$ & \\
\hline Good & 4 & 7,1 & 25 & 44,7 & 27 & 48,2 & \\
& & & & & & & 0,001 \\
Not & 13 & 27 & 8 & 16,7 & 27 & 56,3 & \\
Good & & & & & & & \\
Total & 17 & 16,4 & 33 & 31,7 & 54 & 51,9 & \\
\hline
\end{tabular}

The result based on the analysis using ChiSquare Test showed the P-value 0,001 to Pvalue $<\alpha(0,001<0,05)$, therefore Ho was rejected and it can be concluded that there was a relationship between the level of education and knowledge about contraceptives.

\section{DISCUSSION}

\section{A. The Distribution of Education Levels of Fertile Age Women in Indonesia}

Based on the research that has been done, it was found that from 17 respondents with a Middle School / High School education level who have good knowledge of contraceptives there were 4 people, while 
33 respondents with an education level of D1 / D2 / D3 found there were 25 fertile age women have good knowledge of contraceptives, and 54 respondents with education level Bachelor/Master there were 27 samples who have good knowledge about contraceptives. Setiasih et al., (2016) found that there was a significant effect of education level on the perception of couples of fertile age (PUS) especially women regarding family planning programs $(\mathrm{KB})$ [11]. The higher the education of a woman at fertile age, the more positive their perception of family planning is, and vice versa. Karmila et al. (2020) also states that the low education of women of fertile age will affect the mindset in understanding the importance of using contraceptives and how to use them therefore they do not want to apply it in everyday life [12].

Fertile age women with low education background caused low mindset in understanding the important of using contraceptives. If it is difficult to understand the important of using contraceptives, therefore, it will be difficult to convince about the important of contraceptives in order to help maintain pregnancy distance [12]. Low education will also affect the mindset of fertile age women to accept and understand how to use every available contraceptives so they do not want to use it in everyday life [12].

\section{B. The Education Levels of Fertile Age Women in Indonesia}

Based on the research that has

been done, it was found that there were variety education levels of fertile age women as respondents, it was found 56 respondents with good knowledge and 48 respondents with low knowledge. Mubarak (2011) stated that there were 7 factors can affect the knowledge such as education, occupation, age, interest, experience, environment and information. The information about contraceptives can be obtained through counselling conducted by midwives, doctors and other health workers. Besides, the education levels of each fertile age women itself will help them to understand the knowledge gained [13].

People's knowledge of using contraceptives does not only depend on government or the health workers, however it is also influenced by the education levels of women. Handayani, Beyna, and Nur Indah Rahmawati (2016) stated the result of a research in Argomulyo Village, Bantul, Yogyakarta that the education levels of couples in fertile age either male or female effect the choice of the type of contraceptives they use [14].

The need of contraceptives which unfulfilled is known as unmet need. Listyaningsih, Umi et al. (2016) examined the unfulfilled need for contraceptives in terms of the social background of Fertile Age Couple (PUS) in the Special Region of Yogyakarta (DIY) and Family Planning Field Officers (PLKB). The research stated that many unmet need of family planning was caused by various factors, including women who faced financial, educational, geographical, and social barriers [15]. There were findings in social conditions that lack a high level of unmet need, however, it is also found that there is a high level of unmet need in adequate economic conditions so that education is another factor behind the occurrence of unmet need. Women with unmet need are usually sexually active but do not use contraceptive methods, but they do not want to have more children or delay having another child so that it shows reproductive intentions that are contrary to their behavior [16].

\section{The Relation of Education Levels of Fertile Age Women to Knowledge of Contraceptives in Indonesia}

The result of the research showed that from 104 respondents, there were 56 respondents $(53,8 \%)$ who have good knowledge which from Middle School/High School education levels as many as 4 respondents (7\%), education level D1/D2/D3 as many as 25 respondents (44,7\%), and education level Bachelor/Master as many as 27 respondents 
(48.3\%). Meanwhile, respondents with low knowledge were 48 respondents $(46.2 \%)$ with details of 13 respondents $(27 \%)$ from junior high/high school education levels, 8 respondents (16.7\%) with D1/D2/D3 education levels. and 27 respondents $(56.3 \%)$ with education level Bachelor/Master.

Based on the data that has been presented, it can be seen that the highest frequency with good knowledge was at the level of education D1/D2/D3, which was $75.8 \%$ (Table 2), while the level of education with low knowledge was mostly dominated by Middle School and High School education was $76.5 \%$ (Table 1). This statement was supported by Mubarak (2011) that the level of education was one of the things that affect knowledge because education is an attempt to develop a person's personality and abilities in order to understand something. Education affects the learning process, the higher a person's education, the easier it is for that person to receive information. Knowledge is very closely related to education where it is expected that someone with higher education will have more extensive knowledge [13] .

\section{CONCLUSION}

There were several conclusions based on the results of the research that has been done, they were: respondents which have good knowledge about contraceptives more than respondents which have low knowledge. There was relation between the education levels of fertile age women with the knowledge of contraceptives.

The research we have been doing is using the latest data and sources. This article employed 106 fertile age women from 19 provinces. The article has the respondent's limitation because Indonesia has 34 provinces. For the further research, we recommend to use more respondents and from all province in Indonesia.

\section{REFERENCE}

[1] L. M. Vallely, R. Emori, H. Gouda, S.
Phuanukoonnon, C. S. E. Homer, and A. J. Vallely, "Women's knowledge of maternal danger signs during pregnancy: Findings from a crosssectional survey in Papua New Guinea," Midwifery, vol. 72, pp. 7-13, 2019,

doi: 10.1016/j.midw.2019.02.001.

[2] United Nations. Department of Economic and Social Affairs. Population Division, World Fertility 2019. 2019.

[3] C. Abbafati et al., "Global age-sexspecific fertility, mortality, healthy life expectancy (HALE), and population estimates in 204 countries and territories, 1950-2019: a comprehensive demographic analysis for the Global Burden of Disease Study 2019," Lancet, vol. 396, no. 10258, pp. 1160-1203, 2020, doi: 10.1016/S01406736(20)30977-6.

[4] Badan Pusat Statistik, "Indonesia Population Census 2020," no. 7, pp. 112, 2021.

[5] Badan Pusat Statistik, "Catalog: 1101001," Stat. Indones. 2020, vol. 1101001, p. 790, 2020.

[6] BKKBN, "Rencana Strategis BKKBN 2020," 2020. .

[7] S. E. Vollset et al., "Fertility, mortality, migration, and population scenarios for 195 countries and territories from 2017 to 2100: a forecasting analysis for the Global Burden of Disease Study," Lancet, vol. 396, no. 10258, pp. 12851306, 2020, doi: 10.1016/S01406736(20)30677-2.

[8] H. Kusyanto, "Review Penurunan Fertilitas Di Negara Berkembang : Tren Dan Penjelasan," Publikauma J. Adm. Publik Univ. Medan Area, vol. 5, no. 2, pp. 34-40, 2017, doi: 10.31289/publika.v5i2.1442. 
[9] The World Bank, "Maternal Mortality Ratio (Modeled Estimate, per 100,000 Live Births) - Indonesia | Data," The World Bank, 2019. .

[10] S. Purwanti, "Dampak Penurunan Jumlah Kunjungan $\mathrm{Kb}$ Terhadap Ancaman Baby Boom Di Era Covid-19. vol. XVI, no. 2, 2021.

[11]S. Setiasih, B. Widjanarko, and T. Istiarti, "Analisis Faktor-faktor yang Mempengaruhi Pemilihan Metode Kontrasepsi Jangka Panjang (MKIP) pada Wanita Pasangan Usia Subur (PUS) di Kabupaten Kendal Tahun 2013," J. Promosi Kesehat. Indones., vol. 11, no. 2, pp. 32-46, 2016, doi: 10.14710/jpki.11.2.32-46.

[12] Karmila, F. S. Dewi Harahap, and R. Saragih, "Perspektif Agama Islam Dan Kesehatan Tentang Penggunaan Alat Kontrasepsi (Akjp) Implant Di BPM Keluarga Sehat Kecamatan Darul Hasanah Kabupaten Aceh Tenggara Provinsi Aceh Tahun 2019," J. Healthc. Technol. Med., vol. 6, no. 2, pp. 1000 1013, 2020, doi: 10.33143/jhtm.v6i2.1086.

[13]W. Mubarak, Promosi Kesehatan Untuk Kebidanan. 2011.

[14]B. Handayani and N. I. Rahmawati, "Tingkat Pendidikan PUS Berhubungan dengan Pemilihan Jenis Alat Kontrasepsi tetapi Tidak Berhubungan dengan Keikutsertaan KB di Desa Argomulyo, Sedayu, Bantul, Yogyakarta," J. Ners dan Kebidanan Indones., vol. 4, no. 1, pp. 11-18, 2016, doi: 10.21927/jnki.2016.4(1).11-18.

[15]U. Listyaningsih, S. Sumini, and S. Satiti, "UNMET NEED: KONSEP YANG MASIH PERLU DIPERDEBATKAN," Populasi, vol. 24, no. 1, pp. 72-90, 2016, doi: 10.22146/jp.23696.
[16] World Health Organization South East Asia, UNFPA, and Unicef, "Continuing essential Sexual , Reproductive , Maternal , Neonatal , Child and Adolescent Health services during COVID-19 pandemic Continuing essential Sexual Reproductive, Maternal , Neonatal , Child and Operational guidance for South and South-East Asia," 2020 